\title{
A Cross-Sectional Study on Gender Preference among Mothers of Under Five Children in an Urban Area of West Bengal
}

\author{
Dr Baishakhi Paria ${ }^{1}$, Dr.Agnihotri Bhattacharyya ${ }^{2}$ \\ ${ }^{1}$ Assistant Professor, dept of Community Medicine, Calcutta National Medical College, Kolkata, West Bengal, \\ India \\ ${ }^{2}$ Assistant professor, community medicine, Calcutta national medical college
}

\begin{abstract}
Background: Gender preference especially male preference continues to be a social evil in Indian society. Objective: To study the distribution of the gender preference and to assess whether there is any association between socio demographic factors with this preference and to assess the perception of mothers regarding their ideal numbers of children.

Material and methods: A community based cross sectional study was conducted from April 2015 to September 2015 in urban field practice area of the Calcutta National Medical College, Kolkata among 240 mothers of the under five children.

A structured,pretested interview schedule was used to covering the socio demographic data like mothers age, literacy status, socioeconomic condition, whether elderly female present in the family, number and gender composition of the children, gender preference, history of the abortion, knowledge of the antenatal sex determination, use of contraceptives.

Result: Among the study subjects $28.75 \%$ had male preference. Statistically significant association was found between male preference and education of the mother and gender composition of the children.

Conclusion: Strong preference for male gender was seen among mothers.

Keywords: male preference, gender composition, logistic regression.
\end{abstract}

\section{Introduction}

One of the most significant features of this century has been the decline in fertility and more preference for smaller families, this rather than reducing, has exacerbated male child preference. Fertility decline has been accompanied by a rapid decrease in female births. Sex ratio, an important social indicator measures extent of prevailing equity between males and females in society. Changes in sex ratio reflect underlying socioeconomic, cultural patterns of a society. The male child preference and female feticide is very common practice in Indian society, resulting in declining sex ratio. The most disturbing and alarming aspect of the census report (2001) of India is the sharp fall in the sex ratio of children between the age of 0 and 6 years from 945 in 1991 to 927 in $2001^{3}$. Available data reveals the use of prenatal sex determination techniques (PNDT), as the major cause of decreased female births. An article published in Lancet analysed Indian Census data and concluded that selective abortion of the female foetus has increased in India over the past few decades due to increased prenatal sex determination and has contributed to widening imbalance in the child sex ratio ${ }^{5,6,7}$. The abuse of advanced technologies coupled with social factors such as dowry and looking up to the son as a breadwinner has made the evil practice of female feticide.

The aim of the study is to gauge the preference of the gender of the child among mothers.

\section{General Objective}

\section{Objectives}

To assess the distribution of gender preference among mothers of under five children in an urban area of West Bengal.

\section{Specific Objectives}

1. To find out the association of socio demographic factors responsible for the gender preference.

2. To study the perception of the mothers about the ideal number of the children in the family.

3. To assess any association of the contraceptive practice of the mothers with gender composition of their children. 


\section{Methodology}

A community based cross sectional study was conducted from April 2015 to September 2015 in Baghajatin; ward no 99, urban field practice area of the Calcutta National Medical College, Kolkata. Families were selected by using the following inclusion criteria---Married couples having permanent address and those having under five children. Different authors in different time period had done studies regarding the male gender preference but there is no such literature regarding true male preference. So we pretested the questionnaire in ward no 100 of Baghajatin among 30 mothers. We found prevalence of male preference around $29.9 \%$.

The sample size was determined by using the formula, $4 \mathrm{PQ} / \mathrm{L} 2$,

Where $\mathrm{P}=$ prevalence of the male preference, $\mathrm{Q}=1-\mathrm{P}, \mathrm{L}=$ allowable error.

Considering the prevalence of the male preference to be $29.9 \%$ with the allowable error being $20 \%$ of the prevalence, the initial sample size came out to be 249 . There were 250 mothers who met the inclusion criteria of which nine mothers refused to participate in the study. So final sample size was 240. Informed consent was obtained from all participants, confidentiality was maintained and permission was obtained from institutional ethical committee. The questionnaire was prepared with the help of experts of community medicine departments and modified after pretesting. Mothers were interviewed by home visits after obtaining consent. A structured ,pretested interview schedule was used to covering the socio demographic data like mothers age, literacy status, socioeconomic condition, whether elderly female in the family ,number and gender composition of the children, gender preference ${ }^{2}$

Statistical analysis-Data was analysed by SPSS 18, Epi info 7 and $\chi^{2}$ test was applied to compare various non parametric test. All the variable-associations which showed a $p$ value $<0.2$ were further subjected to a binary logistic regression analysis to determine the factors which were associated with the non-compliance. A $\mathrm{p}$ value of $<0.05$ was considered to be statistically significant

\section{Results}

The present study revealed that $28.75 \%$ of mothers had male preference. Of the total 240 mothers interviewed 69(28.75\%) had male preference. Among them, 77.5\% (186/240) were in the age group of 20-29 years and $154(64.16 \%)$ belonging to Hindu religion. $20.83 \%$ (50/240) were illiterate while $79.17 \%$ (190/240) were literate. Women aged more than 30 years, illiterate, belonging to Hindu religion and having only living female had and those were staying with elderly female more male preference. Statistically significant association was found with education of the mother and male preferences. (Table 1)

A binary logistic regression analysis showed that the gender preference increased as the age increased and that the preference was highest in the age group of 30 years and above. But there was a significantly lower preference among literates $(\mathrm{p}=0.12)$ and among those who had both son and daughter. A significantly higher male preference was found among mothers who had only daughter $(\mathrm{p}=0.001)($ Table 2$)$

When the mothers were interviewed about ideal number and gender composition of the children, majority 166(69.16\%) of the mothers opined two children is the ideal. The ideal gender composition of the children was one son and one daughter as considered by most of the mothers. None of the mothers were in favour of more than three children. An opinion stating only one child as ideal was given by $10.83 \%$ mothers and all of them opined in favour of only son. Similarly opinion in favour of two children was stated by $78.67 \%$ mothers and among them $19.90 \%, 1.4 \%$ opined in favour of only son and one daughter respectively.(Table 3)Association between gender composition of the mother and contraceptive use was found to be statistically significant $(p=0.00),($ Table 4$)$

\section{Discussion}

In India, male preference is very strong and one of the major obstacles in reducing the national fertility level. The present study population showed $28.75 \%$ of the study population had male preference. Dey.I et al ${ }^{\mathrm{r}}$ eported $39.2 \%$ of the rural population of West Bengal had male preference .Similar results were noted in NHFS-2 study where $47 \%$ of the women wanted that the next child to be the male child. The difference were seen may be due to social believes, social customs, social structure between rural urban. A history of abortion was reported $15 \%$ of the mothers and of which $55.56 \%$ were induced. Both of these lower than study done by suburban of Mumbai by Tragler, where abortion was reported in $28 \%$ of the families , of these $79 \%$ were induced abortions. Study showing $67.5 \%$ of the respondents had knowledge about sex determination which almost corroborates $\left(79 \%\right.$ ) with the study conducted in ANC clinic of Ujjaini, M, $\mathrm{P}^{10}$. When the mothers were interviewed about ideal number and gender composition of the children, majority $166(69.16 \%)$ of the mothers opined two children is the ideal. The ideal gender composition of the children was one son and one daughter as considered by most of the mothers. An opinion stating only one child as ideal was given by $10.83 \%$ mothers and all of them opined in favour of only son. Similarly opinion in favour of two children was stated by $78.67 \%$ mothers and among them $19.90 \%, 1.4 \%$ opined in favour of only son and one daughter respectively. 
Dey .I et $\mathrm{al}^{8}$ shows which almost similar picture where majority $(62.8 \%)$ of the mothers considered two to be the ideal number of children and desire for only son was noted in $11.5 \%$ of the mothers compared to $0.6 \%$ who wanted only daughters. This study also revealed that the percentage of women using a contraceptive method increased with the increase in the living sons irrespective of the number of living children [Table 4]. Association between gender composition of the mother and contraceptive use was found to be statistically significant $\left(p=0.00\right.$,). Study done by Dey.I et al ${ }^{8}$ also corroborates similar finding in their study. $(p=0.00)$.

Hussain et al. reported similar observation in the urban settlements of Karachi, where the gender of the living children made influence on the contraceptive use. Similar findings were also noted in a study by Malhi and Raina ${ }^{12}$ carried out in urban Himachal Pradesh study on the teacher couples in Kerala by Gopalkrishnan ${ }^{13}$

\section{Conclusion}

This study revealed a strong preference for male gender and this was significantly associated with older age, illiterate and among those who had single child irrespective of gender of the present study. This calls for setting up gender sensitive educational programmes to abolish the male preference in this community. Similar studies can be conducted involving wider geographical area to assess male preference and taking corrective action.

\section{References}

[1]. Khanna R, Kumar A, Vaghela JF, Srinivasan V, Puliyet JM. Community based Retrospective study of sex in infant mortality in India. BMJ 2003;327: 126-30.

[2]. International Institute of Population Sciences. National Family Health Survey 2, 1998-99. Mumbai: 1999. pp. 111-20.

[3]. Census of India 2001. Available from: http://www.censusindia.net [ accessed on 13 th Oct 2013)

[4]. The Preconception and Prenatal Diagnostics Techniques (Prohibition of sex selection Act, 1994 9 Act No. 57 of 1994) [as amended by the Prenatal Diagnostics Techniques (Reg. and Prevention of misuse) and Act 2002] (Act 14 of 2003).(PNDT Act) The Gazette of India, 2011

[5]. Coale AJ. Excess Female Mortality and the balance of sexes in the population: An estimate of the number of "Missing Females ". Popul Dev Rev 1991;17:517-

[6]. Jha P, Kesler MA, Kumar R et alTrends in selective abortions of girls in India: analysis of nationally representative birth histories from 1990 to 2005 and census data from 1991 to 2011. Lancet. 2011 Jun 4;377 (9781):1921-8.

[7]. Sudha S, Indaya RS. Female demographic disadvantage in India 1981-1991. Sex selective abortions and female infanticide. Dev Change 1999;30:585-618.

[8]. Indira Dey (Pal) et al .Gender preferences and implications on reproductive behaviour of mothers in a rural area of West Bengal. Indian J Community Med. 2009 January; 34(1): 65-67.

[9]. Tragler A. A study on sex ratio at birth in suburban slums of Mumbai. Indian J Public Health 2011;55:128-31

[10]. Khandelwal Vidit et al .Gender preference, attitude and awareness regarding sex determination among married women attending general OPD \& antenatal clinic of RDGMC Ujjain, MP, INDIA .National Journal of Community Medicine Vol 3 Issue 2 AprilJune 2012 .

[11]. Hussain R, Fikree FF, Berendes HW. The role of son preference in reproductive behaviour in Pakisthan. Bull World Health Organ. 2000;78:379-85.

[12]. Malahi P, Raina G. Preferences for the gender of children and its implications for reproductive behaviour in urban Himachal Pradesh. J Fam Welfare. 1999;45:23-30.

[13]. Gopalkrishnan A. Determinants of contraceptive use in Kerala: The case of son or daughter preference. J Fam Welfare. 1994;40:19- 
Table 1 Distribution of study population according to socio demographic characteristics

\begin{tabular}{|c|c|c|c|}
\hline \multirow{2}{*}{$\begin{array}{l}\text { Socio demographic } \\
\text { profile }\end{array}$} & \multicolumn{2}{|c|}{ Male preference } & \multirow{3}{*}{$\begin{array}{l}\text { Statistical Test } \\
\chi^{2}(2)=4.551 \\
\mathrm{p} \text { value }=0.103\end{array}$} \\
\hline & \multirow{2}{*}{$\begin{array}{l}\text { Present } \\
11(30.55 \%) \\
49(26.34 \%) \\
9(50 \%)\end{array}$} & \multirow{2}{*}{\begin{tabular}{l}
\multicolumn{1}{c}{ Absent } \\
$25(69.44 \%)$ \\
$137(73.65 \%)$ \\
$9(50 \%)$
\end{tabular}} & \\
\hline $\begin{array}{l}\text { Age }(\text { yrs }) \\
<19(\mathrm{n}=36) \\
20-29 \text { yrs }(\mathrm{n}=186) \\
30 \text { yrs }(\mathrm{n}=18)\end{array}$ & & & \\
\hline \multicolumn{4}{|l|}{ Religion } \\
\hline $\begin{array}{l}\text { Hindu }(n=154) \\
\operatorname{Muslim}(n=86)\end{array}$ & $\begin{array}{l}40(25.97 \%) \\
29(33.72 \%)\end{array}$ & $\begin{array}{l}114(74.02 \%) \\
57(66.27 \%)\end{array}$ & $\begin{array}{l}\chi^{2}(2)=1.62 \\
\text { p value }=0.2\end{array}$ \\
\hline \multicolumn{4}{|c|}{ Elderly female in the family } \\
\hline $\begin{array}{l}\text { Present }(\mathrm{n}=106) \\
\text { Absent }(\mathrm{n}=138)\end{array}$ & $\begin{array}{l}34(32.07 \%) \\
39(28.26 \%)\end{array}$ & $\begin{array}{l}72(69.92 \%) \\
99(71.73 \%)\end{array}$ & $\begin{array}{l}\chi^{2}\left(1^{)}=1.025\right. \\
p \text { value }=0.311\end{array}$ \\
\hline \multicolumn{4}{|c|}{ Education of the mothers } \\
\hline $\begin{array}{l}\text { Illiterate }(\mathrm{n}=50) \\
\text { Literate }(\mathrm{n}=190)\end{array}$ & $\begin{array}{l}23(46 \%)) \\
46(26.21 \%)\end{array}$ & $\begin{array}{l}27(54 \%) \\
144(74.83 \%)\end{array}$ & $\begin{array}{l}\chi^{2}(1)=9.17 \\
\mathrm{p} \text { value }=0.0024\end{array}$ \\
\hline \multicolumn{4}{|l|}{ Income } \\
\hline $\begin{array}{l}\text { Upper middle and } \\
\text { above }\end{array}$ & $6(21.4 \%)$ & $22(78.57 \%)$ & \multirow[t]{3}{*}{$\begin{array}{l}\chi^{2}\left(2^{\prime}=0.85\right. \\
p \text { value }=0.65\end{array}$} \\
\hline Lower middle & $20(23.25 \%)$ & $46(69.69 \%)$ & \\
\hline Poor and very poor & $43(40.56 \%)$ & $103(70.54 \%)$ & \\
\hline \multicolumn{4}{|c|}{ Different gender composition of the children } \\
\hline $\begin{array}{l}\text { Only living male } \\
(\mathrm{n}=104) \\
\text { Only living } \\
\text { female }(\mathrm{n}=91) \\
\text { Both male and female } \\
\text { present }(\mathrm{n}=45)\end{array}$ & $\begin{array}{l}30(28.84 \%) \\
35(38.46 \%) \\
4(8.88 \%)\end{array}$ & $\begin{array}{c}74(71.15 \%) \\
56(61.53 \%) \\
41(9.11 \%)\end{array}$ & $\begin{array}{l}\chi^{2}\left(2^{\prime}=12.856\right. \\
p \text { value }=0.002\end{array}$ \\
\hline
\end{tabular}

Table no 2: Logistic regression analysis of the attributes found to be significantly associated with male

\begin{tabular}{|l|l|l|}
\hline Factors & $\begin{array}{l}\text { Odds ratio } \\
\text { (95\% confidence interval) }\end{array}$ & P value \\
\hline Age(yrs) & $0.303(.083-1.1)$ & 0.069 \\
\hline$<19$ & $0.322(0.107-0.970)$ & 0.044 \\
\hline $20-29$ & 1 & \\
\hline 30 & 1 & 0.12 \\
\hline Education & 1 & 0.008 \\
\hline Literate & $2.494(1.218-5.106)$ & 0.001 \\
\hline Illiterate & $4.70(1.508-14.647)$ & \\
\hline Gender composition & $6.929(2.224-21.591)$ & \\
\hline Only male child present & 1 & \\
\hline Only female child present & & \\
\hline $\begin{array}{l}\text { Both male and female child } \\
\text { preference }\end{array}$ & \\
\hline
\end{tabular}

Table 3: Distribution of mothers according to their views regarding the ideal number of children in the family.

\begin{tabular}{|l|l|}
\hline Ideal composition of child & Number $(\%)$ \\
\hline One child & $26(10.83 \%)$ \\
\hline 1 son & $26(100)$ \\
1 daughter & - \\
\hline
\end{tabular}


A Cross-Sectional Study on Gender Preference among Mothers of Under Five Children in an Urban ..

\begin{tabular}{|l|l|}
\hline Two child & $211(100)$ \\
\hline 1 son and 1 daughter & $166(78.67)$ \\
2 daughters & $3(1.4)$ \\
2 sons & $42(19.90)$ \\
\hline Three & $3(100)$ \\
\hline 2 sons and 1 daughter & $3(1.25)$ \\
3 sons & - \\
3 daughter & - \\
\hline Total & $240(100)$ \\
\hline
\end{tabular}

Table 4-Association between gender composition and contraceptive practice among study population

\begin{tabular}{|l|l|l|l|}
\hline \multirow{2}{*}{ Gender composition } & \multicolumn{2}{|c|}{ Contraceptives } & \\
\cline { 2 - 3 } & Used & Not used & $\begin{array}{l}\chi^{2}=38.10(2) \\
\mathrm{P}=0.00 \text { (significant) }\end{array}$ \\
\hline $\begin{array}{l}\text { Only male child } \\
\text { present(n=104) }\end{array}$ & $63(60.57 \%)$ & $41(39.63 \%)$ & \\
\hline $\begin{array}{l}\text { Only female child } \\
\text { present(n=91) }\end{array}$ & $21(23.07 \%)$ & $70(76.92 \%)$ & \\
\hline $\begin{array}{l}\text { Both male and female child } \\
\text { present(n=45) }\end{array}$ & $35(77.77 \%)$ & $10(33.33 \%)$ & \\
\hline
\end{tabular}

